\title{
Preparation of raw materials, creation of compositions and granulation from obsolete sludge, peat and biomass
}

\author{
Zh.O. Petrova (ORCID 0000-0001-7385-8495), Yu.P. Novikova (ORCID 0000-0002-6705-1000) \\ Institute of Engineering Thermophysics of NAS of Ukraine, str. Bulakhovskogo, 2, Bldg. 1, Kyiv, 03164, Ukraine \\ Tel.: +380444249639, +380635275640 \\ E-mail: bergelzhanna@ukr.net,yuliianovikova3@gmail.com
}

Article info: received 04.02.2021, revised 17.02.2021, accepted 23.03.2021

Petrova, Zh.O., Novikova, Yu.P. (2021) Preparation of raw materials, creation of compositions and granulation from obsolete sludge, peat and biomass 1(50), DOI: 10.26909/csl.1.2021.2

The article presents research on the preparation of raw materials, creation and granulation of compositions from obsolete sludge deposits of peat and biomass. Studies of raw material preparation processes have shown that obsolete sludge deposits have excessive ash content. To reduce ash content, it is advisable to add peat and biomass to sludge. During the study of peat, it was determined that peat extracted from the floodplain of Irpen has a high ash content, so for further research used peat from Chernihiv.

The created compositions were subjected to granulation in different compositions and ratios. Preliminary dehydration of peat in the drying cabinet and moistening of the sludge were performed to create different sludge-peat mixtures with different moisture content of sludge and peat. When creating two-component compositions to sludge-peat add biomass. Studies have allowed us to choose the optimal ratio for granulation.

Key words: sludge, peat, biomass, preparation, granulation.

\section{Підготовка сировини, створення композицій та гранулоутворення з застарілих мулових відкладень, торфу та біомаси}

\author{
Ж.О. Петрова, Ю.П. Новікова \\ Інститут технічної теплофізики НАН України, Киї, Україна
}

У статті наведені дослідження з підготовки сировини, створення та гранулоутворення композицій $з$ застарілих мулових відкладень, торфу та біомаси. Проведені дослідження процесів підготовки сировини, показали, що застарілі мулові відкладення мають перевищену зольність. Для зменшення зольності до мулових осадів доцільно додавати торф та біомасу. При досліджені торфу було визначено, що торф добутий з пойми міста Ірпеня має високу зольність, тому для подальших досліджень використано торф з міста Чернігова.

Створені композиції піддавали гранулюванню при різних композиціях та співвідношеннях. Для створення різних мулоторф'яних сумішей із різною вологістю мулу та торфу проводили попереднє зневоднення торфу в сушильній шафі та зволоження мулу. При створенні трьохкомпонентних композицій до мулоторф'яних сумішей додаємо біомасу. Проведені дослідження дозволили підібрати оптимальне співвідношення для гранулювання.

\section{Вступ}

В Україні існує проблема так званих мулових майданчиків з муловими відкладеннями, яким понад 30 років. Ці відкладення майже не мають органічних домішок, що ускладнює процес їх переробки. Обмежене використання мулових відкладень обумовлене наявністю великої кількості мінеральних та токсичних речовин і відсутність технології їх утилізації [1].
Мета роботи полягає у проведенні дослідження процесів підготовки та гранулоутворнення композиції на основі мулових відкладень, торфу та біомаси для подальшої обробки.

\section{Матеріали та методи дослідження}

Створення композицій проводилося з застарілих мулових осадів очисних споруд (м. Фастів), торфу та біомаси у різних співвідношеннях. До компози- 
цій додавався торф з родовища ДП «Чернігівторф» (м. Чернігів) та з пойми Ірпеня. Біомасу додавали на прикладі тирси та лузги гречки.

Застарілий муловий осад доставлений 3 м. Фастова Київської області і мав початкову вологість $63,1 \%$, органічну складову - 53,7 \% до абс. сухої маси та зольність - 47,3 \% до абс. сухої маси (рис. 1).

В лабораторії відділу ТМПТ Інституту технічної теплофізики НАН України проведені дослідження із визначення вологості та зольності мулових відкладень, торфу, лузги гречаної, тирси та створені на їх основі дво- та трьохкомпонентні композиції (рис. 1).

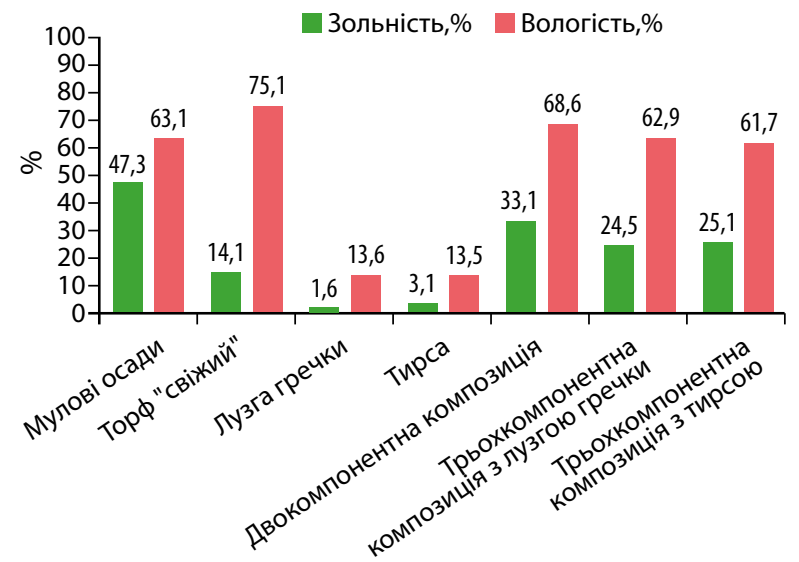

Рис. 1. Визначення зольності і вологості мулових осадів, торфу, лузги гречки, відходів деревини

(тирси) та їх композицій

\section{Результати та їх обговорення}

3 рисунка 1 видно, що зольність мулових осадів становить 47,3 \%, що не допустимо при спалюванні. Торф з родовища ДП «Чернігівторф» має достатньо низку зольність 14,1%. При поєднані цих матеріалів зольність композиції становить 33,1 \%, що також перевищує допустимі норми при спалюванні гранул. Зольність біомаси у тирси $-3,1 \%$, а лузги гречки - 1,6 \%. Для підвищення якості і зменшення зольності мулоторфяних гранул доцільно до них додавати тирсу та лузгу гречки. Зольність трьохкомпонентних сумішей становить $25 \%$.

Приготування композицій проводили за етапами:

1. При приготуванні робочої суміші з чистого застарілого мулу проводився відбір 3 нього дрібного каміння, пробок від пластикових пляшок, плівки та іншого сміття значних розмірів.

2. При наявності грудок торф розтирався до однорідної маси. Біомаса розмелювалася до мілкої фракції.

3. Після цього замішувався мул з торфом вруч- ну у різних пропорціях з утворенням мулоторф'яної суміші. При замішуванні був відчутний неприємний запах.

4. Під час створення трьохкомпонентних композиції до мулоторф'яної композиції додавалася тирса або гречана лузга (визначено умовами гранулювання).

5. Для створення мулоторф'яних сумішей із різною вологістю мулу та торфу проводили їх попереднє зневоднення в сушильній шафі.

6. Створені композиції залишали на деякий час для усереднення.

На основі застарілих мулових відкладень з вологістю 63,1 \% та торфу з вологістю 75,1% при змішуванні в підібраних пропорціях були створені різні комбінації. Композиції замішувались досить легко на протязі 5 - 10 хв.
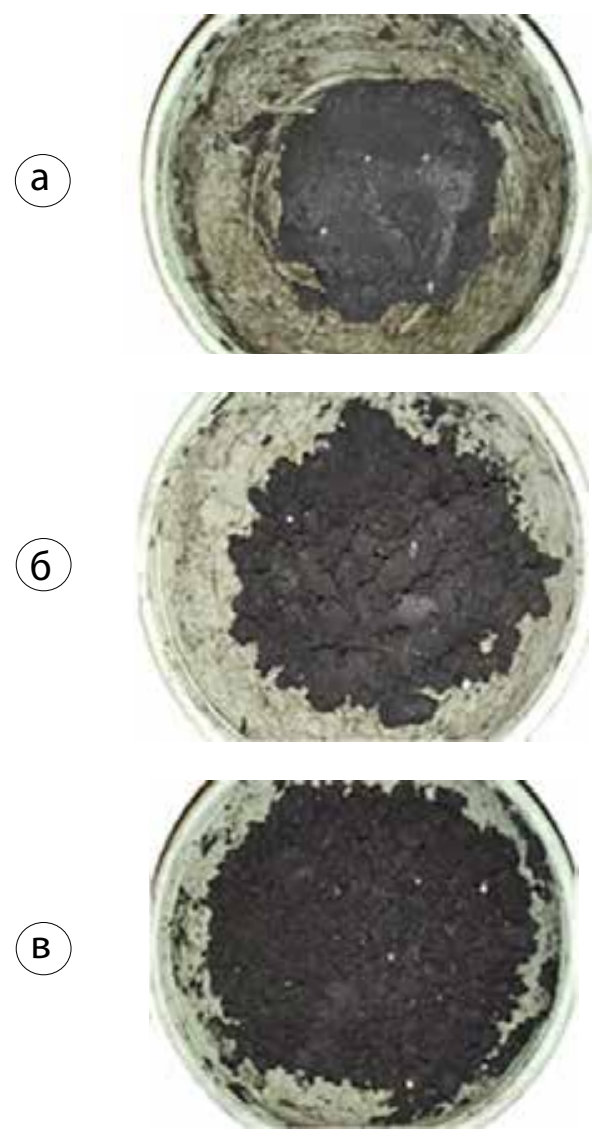

Рис. 2. Композиції: а) співвідношення 1;

б) співвідношення 2; в) співвідношення 3

Перше співвідношення: мало вигляд однорідної густої пасти (рис. 2 а) [1]. Друге співвідношення: мало вигляд однорідної розсипчастої маси, яка місцями зліплена в грудки (рис. 2 б) [2]. Третє співвідношення: мало вигляд однорідної розсипчастої маси (рис. 2 в) [3]. 
Після замішування сумішей їх гранулювали в гідравлічному пресі HLR - 12 під тиском 2,118 2,197 МПа. Для отримання необхідної кількості кожну суміш гранулювали на протязі 1 години.
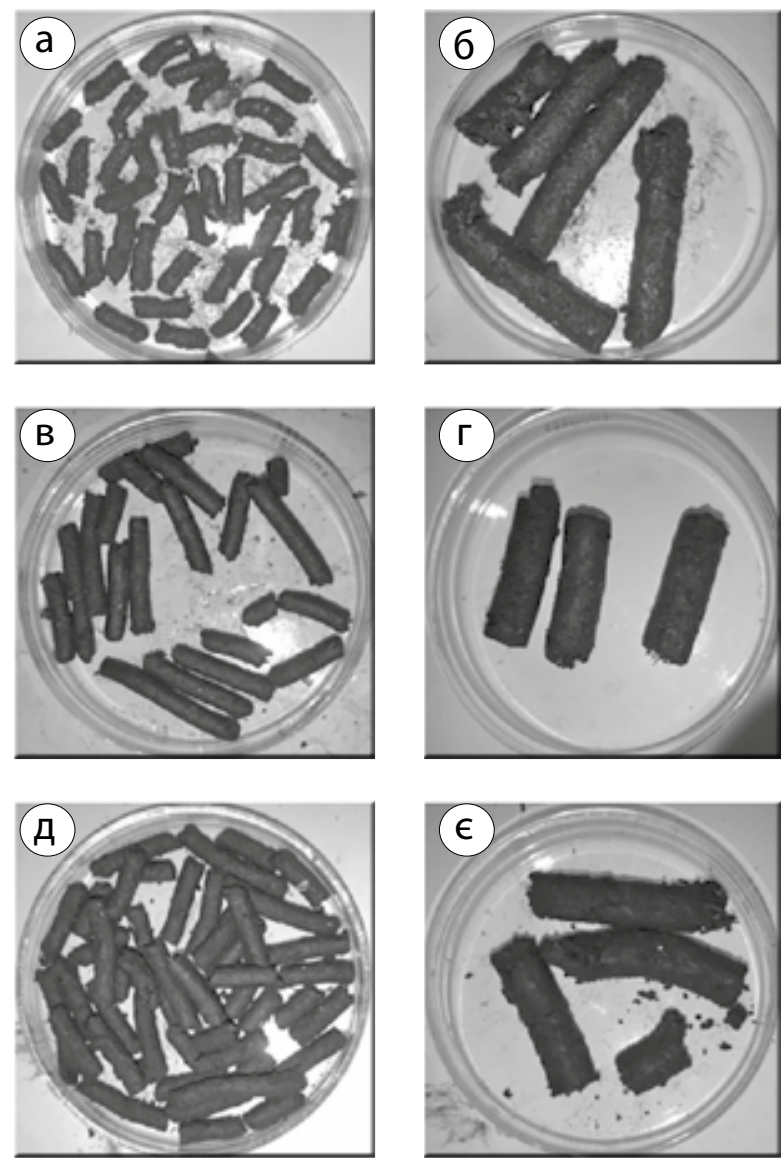

Рис. 3. Отримані гранули з суміші:

- співвідношення 1: а) $d=6 \mathrm{мм}$; б) $d=12 \mathrm{мм}$;

- співвідношення 2: в) $d=6$ мм; г) $d=12$ мм;

- співвідношення 3: д) $d=6$ мм; є) $d=12$ мм
Гранули за першою комбінацією вологі, слизькі, м'які, при малих навантаженнях руйнують форму та злипаються (рис. 3 а, б). В порівнянні 3 першою гранули за другою комбінацією твердіші, руйнують форму при більших навантаженнях та не злипаються (рис. 3 в, г). Гранули за третьою комбінацією самі тверді в порівнянні з двома іншими, крихкі та не злипаються (рис. 3 д, є) [1 - 3].

В результаті змішування двокомпонентної композиції (торф 3 «Чернігівторф», застарілі мулові відкладення 3 м. Фастів) різної вологості та пропорції були отримані мулоторф'яні гранули з різною початковою вологістю (рис. 4).

Композиція 1 та 2 створенні з мулових відкладень вологістю 63,1 \% та торфом з вологістю 75,1 \% та 45,1 \% відповідно. Композиція 3 та 4 - з мулових відкладень вологістю 70,1 \% та торфом з вологістю 75,1 \% та 45,1 \% відповідно. Композиції 5, 6, 7 - 3 мулових відкладень вологістю 75,9 \% та торфом 3 вологістю 75,1\%, 45,1\% та 20,1\% відповідно.

При вологості мулу 63,1 \% та 70,1 \% при замішуванні з торфом вологістю 45,1% сформовані гранули були крихкими та розсипалися, тому з торфом 20,1 \% створення композицій не доцільно. В композиції 7 гранули були сформовані тільки за першим співвідношенням.

На рис. 5 зображено зміна зольності та вмісту органічних речовин в залежності від співвідношення складу гранул. Чим більше в співвідношенні мулових відкладень тим більше зольність та менше вміст органічних речовин.

Також створені трьохкомпонентні композиції 3 торфу з вологістю 75,13 \%, зольністю 14,11 \%; застарілі мулові осади 3 вологістю $63 \%$, зольністю $47,33 \%$ та біомаса (лузга гречки з вологістю $13,6 \%$, зольністю 1,6 \%; відходи деревини (тирси) з вологістю $13,5 \%$, зольністю $3,1 \%$ ).

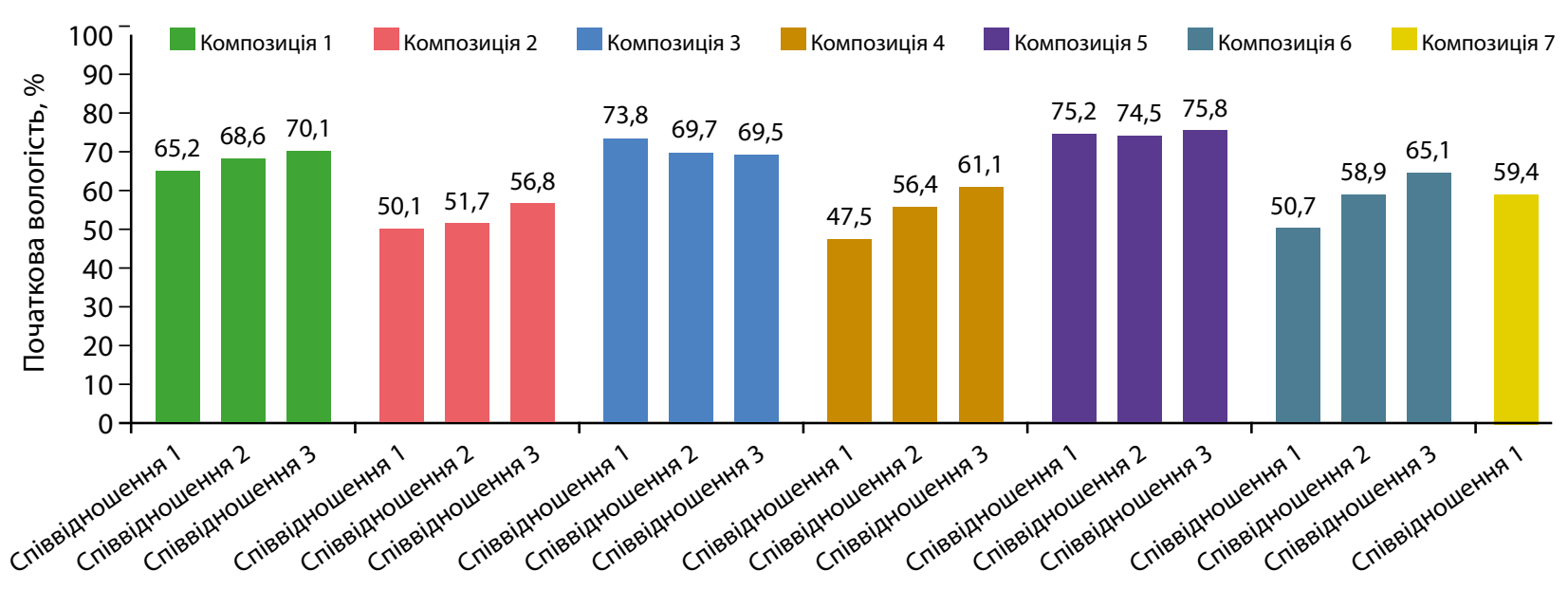

Рис. 4. Змінна початкової вологості в залежності від композиції та співвідношення складу гранул 


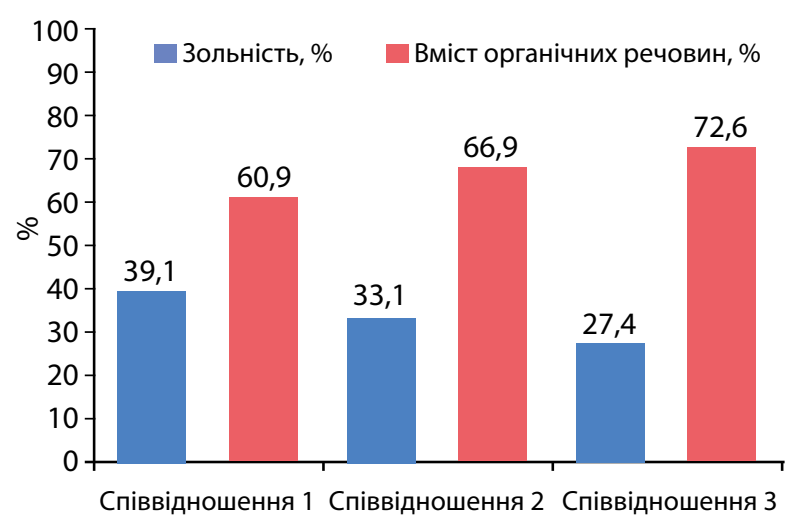

Рис. 5. Зміна зольності та вмісту органічних речовин в залежності від співвідношення складу гранул
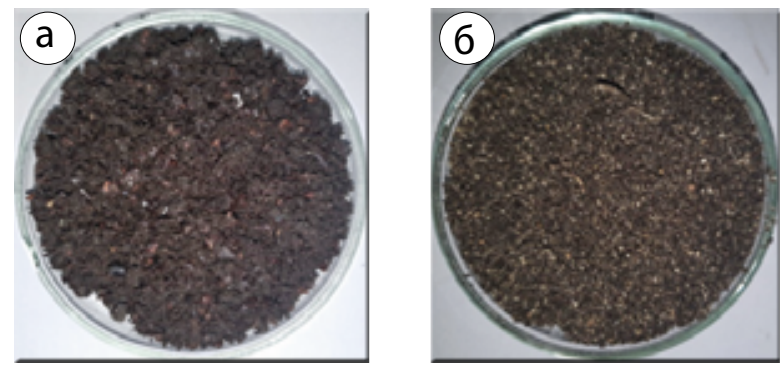

Рис. 6. Трьохкомпонентні композиції: а) 3 лузгою гречки; б) 3 тирсою

Композиція з лузгою гречки комкувалася (рис. 6 a). Композиція з тирсою була розсипчастою (рис. 6 б). Гранули формували під тиском 1,961 - 3,923 МПа. Сформовані гранули 3 трьохкомпонентних композицій не злипаються, при невеликих навантаженнях руйнуються (рис. 7).
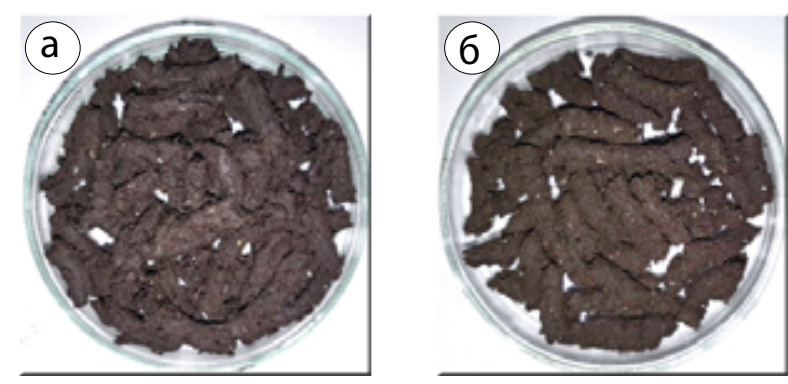

Рис. 7. Отримані трьохкомпонентні гранули: а) з лузгою гречки; б) 3 тирсою

Як видно з рис. 8, трьохкомпоненті гранули мають меншу зольність та більший вміст органічних речовин в порівнянні з двокомпонентними.

Створені композиції на основі застарілих мулових відкладень 3 вологістю 63,1 \% та торфу з пойми Ірпеня з вологістю 55,13 \% та зольністю 47,3 \% ви-

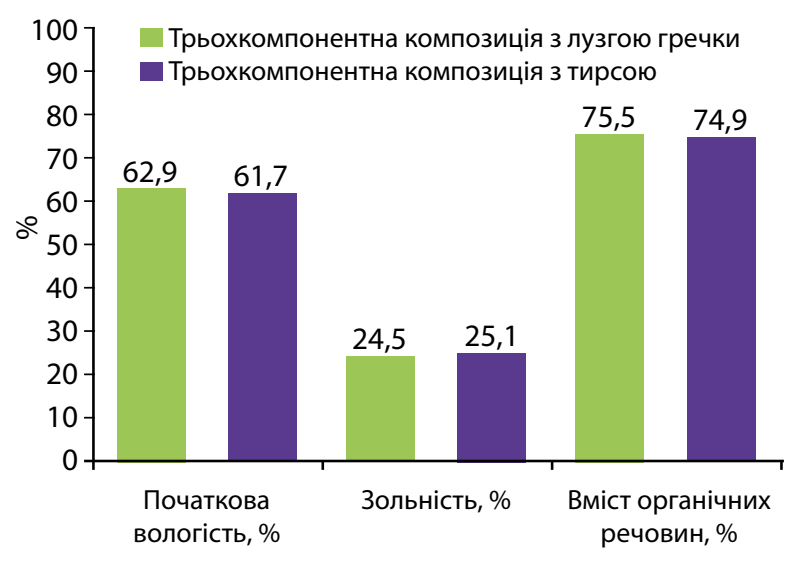

Рис. 8. Зміна початкової вологості гранул, зольності та вмісту органічних речовин від складу композиції

глядали так само, як із торфом з ДП «Чернігівторф», але формування суміші було довше. Перше співвідношення: легко замішувалась на протязі 10 хвилин, після цього суміш мала вигляд однорідної густої пасти. Друге співвідношення: в порівняні з першою замішувалась складніше на протязі 15 хвилин, після цього суміш мала вигляд однорідної розсипчастої маси, яка місцями зліплена в грудки. Трете співвідношення: замішувалась досить складно на протязі 20 - 25 хвилин, після цього суміш мала вигляд однорідної розсипчастої маси.

Як видно з рисунка 9, композиції з торфом 3 пойми Ірпеня мають перевищену зольність, яка більше допустимих норм при спалюванні. Тому ці гранули не підходять для подальшої роботи.

Створені дво- та трьохкомпонентні суміші гранулювали і піддавали сушінню на конвективному сушильному стенді.

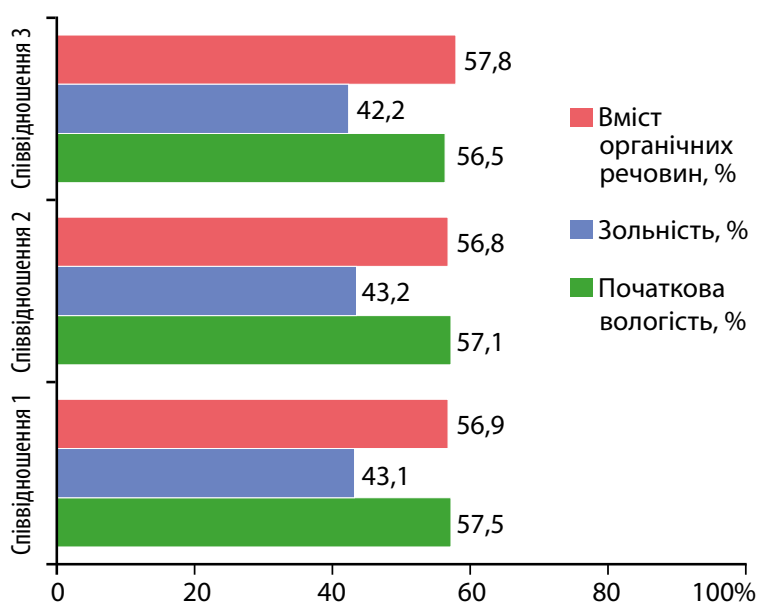

Рис. 9. Зміна початкової вологості гранул, зольності та вмісту органічних речовин від складу композиції 


\section{Висновки}

Проведені дослідження 3 визначення зольності показали велику кількість золи в відкладеннях, що потребує їі зменшення. Для пониження зольності використано торф та біомасу. При дослідженні властивостей торфу було визначено, що торф з пойми Ірпеня має перевищену зольність, яка не допустима при спалюванні, тому для подальшої роботи використано торф з ДП «Чернігівторф». Підібрано оптимальне співвідношення компонентів 3 метою якісного гранулювання. Створення композицій підвищує якість та зменшує зольність.

\section{References}

1. Petrova, Zh.O., Kremnov, V.O., Korbut, N.S., Novikova, Yu.P. Granulation of mixtures of obsolete sludge and peat. Удосконалення процесів та облад- нання харчових та хімічних виробництв: збірник тез доповідей XVIII міжнародної наукової конференції, м. Одеса, 12 - 16 жовтня 2020 р. - Одеса: ОНАХТ. 2020. - C. 14 - 16.

2. Petrova, Zh., Pazyuk, V., Novikova, Yu., Stetsyuk, $V$. Granulation of compositions from obsolete sludge and peat. Проблеми сучасної теплоенергетики: збірник тез доповідей міжнародної науково-практичної конференції, присвячується 100-річчю професора Драганова Бориса Харлампійовича, Київ, 10 - 11 грудня 2020 р. - Київ: НУБіП. - 2020. C. 109 - 111.

3. Петрова, Ж.О., Новікова, Ю.П. Гранулювання композицій з застарілих мулових осадів та торфу. Ресурсоенергозберігаючі технології та обладнання: збірник тез доповідей XIX міжнародної науково-практичної конференції студентів, аспірантів і молодих вчених, Київ, 25 - 26 листопада 2020 р. - Київ: «КПІ ім. Ігоря Сікорського». - 2020. - С. 54 - 55. 